\title{
SPLIT SALES OF GAS
}

\author{
ROBERT C. MUIR*
}

The Natural Gas Industry is highly competitive and once a gas reservoir is discovered the various producers are anxious to enter into Gas Purchase Contracts. The contracts are with different purchasers and on different terms giving rise to split stream deliveries-there would never be any split stream problems if all producers made simultaneous deliveries to one or more purchasers in exactly the same volumes at exactly the same price. This article examines the position of the producers in the gas reservoir in the absence of an agreement and then discusses different contractual methods which the producers may use to resolve the conflict between the Doctrine of Correlative Rights and the Rule of Cap. ture, such as gas market sharing contracts, cash adjustments, gas balancing schemes and deferred production agreements. To further complicate the prob. lems of the producer in dealing with split sales of gas, the lessee-producer must keep in mind the interests of the lessor-royalty owner. The article concludes with a consideration of the interest of the royalty owner in the prepayment received by the producer and in the price for which the producer is selling the gas.

\section{A. INTRODUCTION}

A newly-discovered gas pool presents an interesting legal panorama. Original owners of the gas in place will usually have leased their rights to producing companies reserving a royalty on gas produced. Producing companies may have entered into farmout agreements, pooling agreements and other operating agreements covering some tracts of land in the pool. Preliminary discussions leading to unitization are under way. Some producers are parties to gas sales contracts with one or other of the major gas export companies and some of these contracts provide for prepayment of sales gas prices. We will examine a number of situations which can arise out of this melange of interests.

\section{B. BACKGROUND}

The discovery of natural gas is only the first step in a long sequence of technical and legal events preceding burner tip use. In Western Canada natural gas is particularly sour having a ratio of 44 barrels of liquids and 2.3 tons of sulphur per million cubic feet. ${ }^{1}$ The residue gas delivered by producers to purchasers under gas sales contracts must be in a form which is usable by the ultimate customer and relatively non-polluting in the location in which it is used. Accordingly, large and expensive gas processing plants must be built by the producers to render the natural gas into a marketable form which will meet purchaser's specifications. Canadian gas processing plant capacity, over $90 \%$ of which is located in Alberta, totals 11 bcf per day of raw input gas with an output of 9.7 bcf per day of residue gas, 15.8 thousand tons per day of sulphur and 315 thousand barrels per day of propane, butane and pentanes plus. Forecasts are that capital expenditures on new plants will be $\$ 2$ billion in the 1970's.

The reservoir characteristics of gas are such that a pool can be depleted by production through a small number of wells. It is neither

- B.Sc., L.L.B (Man.) of the Alberta and Manitoba Bars. Manager, Legal Dept. Home Oil Company Limited, Calgary, Alberta.

1 These and other statistics in this section are from the Canadian Petroleum Association, American Petroleum Institute and American Gas Association. 
necessary nor desirable that a well be drilled on each production spacing unit. Accordingly, most gas pools are unitized by agreement between the producers and the royalty owners. All natural gas produced is allocated to the various leased tracts in the unit, each tract receiving an agreed upon percentage share of total gas produced. The allocation is a legal allocation and deems that natural gas allocated to each tract, and only that gas, is produced from that tract. Physically, the gas moves from the wells through a gathering system to a gas processing plant owned by the producers and constructed and operated by them pursuant to a plant agreement. Because of long delays in obtaining delivery of plant vessels and equipment, agreements for the construction and operation of the plant will have been executed long before the unitization is effective, so that the timing of plant completion is in line with the effective date of unitization. The plant is normally not a unit facility. Because of the impossibility of predicting with certainty as to which producers may or may not join the unit, the gathering system is usually constructed pursuant to a third agreement and is often neither a unit nor a plant facility.

Raw sour natural gas is processed in the plant to produce marketable residue gas, propane, butane, pentanes plus and sulphur. In $\mathrm{Al}$ berta, the residue gas is delivered into the lines of the Alberta Gas Trunk Line Company, a statutory corporation, ${ }^{2}$ which gathers gas from various fields and plants within Alberta for delivery to the purchasing transmission companies. Gas in the lines of Alberta Gas Trunk is owned by the purchasing transmission company from time of delivery from the producer. After leaving the Alberta Gas Trunk system the residue gas moves in the purchasing company's lines to customers in Alberta, or outside Alberta in other parts of Canada or in the United States. Gas sales in 1969 totalled approximately 1.4 tcf of which 800 bcf were sold within Canada and 625 bcf were exported to the United States. Pipeline sales revenues were $\$ 685$ million. Forecasts are that by 1980 , annual domestic sales will exceed 2 tcf and export sales 2.3 tcf with annual pipeline revenues totalling $\$ 2$ billion. Gross production revenue of gas, liquids and sulphur could reach $\$ 1.5$ billion annually by 1980 , up from today's annual $\$ 500$ million revenue.

Alberta government approval is required before any gas can be exported from Alberta. ${ }^{3}$ Further, the export from Alberta of any gas which is the subject of a Crown lease without the approval of the Lieutenant Governor in Council renders the lease void. ${ }^{4}$ Similarly, Federal government approval is required before any gas can be exported from Canada. ${ }^{5}$ Upon application for export both the Alberta Oil and Gas Conservation Board and the National Energy Board consider, among other things, evidence as to future availability of gas for Alberta or Canadian needs. Canadian gas reserves in 1969 totalled 51.9 tcf having a reserves life index of 34.2 years. In 1969, 5.8 tcf of new gas reserves were discovered, 1.5 tcf were produced leaving a net gain for the year of 4.3 tcf. Reserves now authorized for export to the United States and for which application for export is pending total 2.2 tcf. To maintain a 25-year reserves life index and to meet

\footnotetext{
2 The Alberta Gas Trunk Line Company Act, S.A. 1954 c. 37 , as amended.

1 The Gas Resources Preservation Act, S.A. 1956, c. 19, as amended.

- Clause 6 - Government of Alberta Standard Form of Petroleum and Natural Gas Lease.

s Sec. 81, National Energy Board Act, S.C. 1959 c. 46, as amended.
} 
1979 gas sales volumes, approximately 85 tcf of new reserves will have to be found in the next decade.

Propane, butane, pentanes plus and sulphur, subject to the condition of the market for each, are separately sold on short-term contract to various customers. The short-term nature of the market arrangement for these gas by-products and the relative convenience of storage of some of these products minimize most problems arising out of their production. This paper deals mainly with residue gas sales.

Oil, by its nature, is readily transportable by a variety of methods to refinery and ultimate point of sale. Though there were chaotic early years in the oil industry which saw wild fluctuation of sales prices and availability of supply, arrangements were gradually achieved which removed a great deal of the uncertainty in the marketing of crude oil. The tradition in the oil industry has been that oil is sold by the producer on a short-term basis. On the other hand, until quite recently gas was regarded as a nuisance which, at best, interferred with the proper business of crude oil production. It was either flared or abandoned when encountered. A sudden development of market in the past few decades required the construction of trans-continental transmission lines to bring gas from remote areas to large consuming centers. Concern as to the security of a particular project was not confined to the promoters of the purchasing transmission company but was shared by the financial houses which were lending the money, the distributors who were buying the gas from the transmission company for resale to customers, the customers who would be installing equipment to utilize the gas, governments which preferred an orderly business climate and a guarantee that domestic consumers in the provincial or federal producing jurisdiction be assured of a continuous supply of gas, and the producers who were required to construct expensive processing facilities to handle a substance recently regarded as useless. Accordingly, a deep and abiding interest in seeing that gas supplies and markets would be available over the long term became a key factor in the gas business. ${ }^{6}$ This concern prevails today despite the fact that Canadian gas reserves to meet future needs are at least as secure as oil reserves, that gas in large quantities could be stored in underground caverns and that transportation of methane in liquid form is possible though expensive. For the historical reasons outlined above, gas is usually sold under long-term contract running from 20 to 25 years.

The Alberta Gas Trunk system mentioned above is effective in opening saleable reserves to competition between various purchasers. During periods when the purchasing companies are anxious to contract for gas, producers are in the fortunate position of being able to pick and choose between buyers. On the other hand, in periods when purchasing companies are not so anxious, a producer who misjudges the situation may find himself without a market. These factors are the source of most gas sales problems.

The overriding legal consideration at the field end of the industry involves the right of an individual producer to take gas from a common pool. The basis of this right is the law or rule of capture, an

" For a fascinating history of one segment of the Canadian Natural Gas Industry see Kilbourn, Pipeline Trans-Canada and the Great Debate, Clarke, Irwin \& Co. Ltd. 
authoritative statement of which, as it applies in Canada, is that of Lord Porter in the Privy Council judgment in Borys v. C.P.R.: ${ }^{7}$

If any of the three substances [gas, oil and water] is withdrawn from a portion of the property which does not belong to the appellant but lies within the same container and any oil or gas situated in his property thereby filters from it to the surrounding lands, admittedly he has no remedy. So, also, if any substance is withdrawn from his property, thereby causing any fugacious matter to enter his land, the surrounding owners have no remedy against him. The only safeguard is to be the first to get to work, in which case those who make the recovery become owners of the material which they withdraw from any well which is situated on their property or from which they have authority to draw.

Thus the law of capture preserves to a producer the fruits of his industry in producing from a common source of supply and gives to the neighbour an opportunity to develop the substances underlying his own land. Baldly stated, the law of capture runs counter to sound conservation practices and could, if not curbed by conservation legislation, lead to undesirable results. ${ }^{8}$ In Alberta, legislation (or regulation pursuant to legislation $)^{9}$ prohibits certain forms of waste, requires wells to be drilled at certain distances from property lines and on tracts of land containing a specified number of acres. There is legislation setting conservation allowables with respect to oil and gas production from wells and providing for compulsory pooling. The cumulative effect of this conservation legislation has been to curtail and limit the right of the individual to operate as he pleases without regard to the public interest or to the private interests of other persons owning mineral rights in the reservoir. Thus the practical impact of the law of capture is limited but, as we shall see, it is not limited nor would it be practical to limit it, so that gas sales problems are eliminated.

\section{FAILURE TO PRODUCE AND SELL GAS BY REASON OF LACK OF MARKET}

\section{Rights of Non-Producing Lessees}

Assume producers A, B, C and D are lessees of tracts of land in a gas pool. A and B each have an undivided 50\% interest in a section of land comprising a gas spacing unit on which a gas well is located. $\mathrm{C}$ and $\mathrm{D}$ are each lessees of separate tracts on each of which there is also located a gas well. A, C and D have entered into gas sales contracts with pipeline export company $\mathrm{X}$ and $\mathrm{B}$ has not. $\mathrm{B}$ wishes to sell its gas to $\mathrm{X}$ on the same basis as $\mathrm{A}, \mathrm{C}$ and $\mathrm{D}$, but $\mathrm{X}$ will not purchase the gas because it does not require it to meet customer demand.

Three possible courses of action whereby B may obtain revenue are:

(1) an application for an injunction to prevent A from producing in the hope of forcing $A$ to share his market;

(2) an action for an accounting by A to B for $50 \%$ of the proceeds of gas revenue received by $\mathrm{A}$ from $\mathrm{X}$; or

(3) an application to the Oil and Gas Conservation Board for an Order declaring $\mathrm{X}$ to be a common purchaser of gas from the pool.

? [1953] A.C. 217 at $220 ; 7$ W.W.R. (N.S.) 546 at 550 ; (1953) 2 D.L.R. 65 at 68 . See also Imperial Oil Ltd. v. Placid Oil Co. [1963] S.C.R. 333; 40 W.W.R. (N.S.) 412; 36 D.L.R. (2d) 122.

- See "Rule of Capture and Correlative Rights," Lewis and Thompson, Canadian Oil and Gas, Vol. 1, Div. A, Para. 44-45.

9 The Oil and Gas Conservation Act, 1969, S.A. 1969 c. 83, as amended and the Oil and Gas Conservation Regulations, Alberta Regulation 183/69, as amended. 
Dealing with (1) and (2), we see that A and B are concurrent owners in the gas spacing unit on which their well is located and of any gas produced from the well. ${ }^{10}$ Two English Statutes ${ }^{11}$ of 1285 and 1705 lay down that a co-tenant is liable to his co-tenant for waste and that an Action of Account may be maintained by one co-tenant against the other as bailiff "for receiving more than comes to his just share or proportion".

In the United States, the majority of producing states (including Texas, California, Oklahoma and Pennsylvania) do not regard production of oil or gas as waste. They allow a co-tenant to produce without consent of his co-tenant and entitle the non-consenting co-tenant to his proportionate share of proceeds of production. ${ }^{12}$ No injunction will lie at the instance of one co-tenant to prevent the other co-tenant from producing unless that other co-tenant is attempting to deny the first mentioned co-tenant use and enjoyment of the concurrently-owned property. ${ }^{13}$ On the other hand, Illinois, Louisiana and West Virginia hold that extraction of oil or gas is waste, that an injunction will lie at the suit of the non-consenting co-tenant, that if there is removal of the substance by one co-tenant he must account to the other, but that, in order to prevent undue drainage through wells on other lands, production by one co-tenant for accounting to the other may be allowed. ${ }^{14}$

There are no Canadian oil and gas cases determining whether one or another of the above principles is to be followed in Canada. However, "if a substantial portion of the economic value of land is represented by the minerals contained therein, denial of the right of a concurrent owner to remove minerals represents the denial to him of the beneficial enjoyment of his interest in the land."15 Accordingly, a nonconsenting co-tenant's right to obtain an accounting for the proceeds of production would afford him reasonable protection.

Assuming then that Canadian courts will follow the lead of the courts of the majority of United States producing states, the injunction course of action will not be open to B. A may produce and sell gas but is required to account to $B$. The basis of accounting in the majority of states is that the non-consenting co-tenant is to receive his proportionate share of proceeds of production less his proportionate share of reasonable and necessary costs of drilling and production. ${ }^{16}$ In Canada, it is at least arguable that, in a case where one co-tenant has proceeded to drill and produce, he should be entitled to a fair and reasonable profit and not be obligated to account to his non-joining cotenant for a proportionate share of proceeds less a proportionate share of operating costs. In Spelman v. Spelman, ${ }^{17}$ a husband-wife dispute over profits made running a rooming house, the court quoted extensive-

\footnotetext{
10 Olisa, Legal Problems Arising Out of Co.ounership of Oil and Gas Leasehold Estate and Facilities, (1970) 8 Alta. L. Rev. 177.

" Statute of Westminster II (1285) 13 Edward 1, c. 22. Statute of 4 Anne (An Act for the Amendment of the Law and the better Advancement of Justice) (1705) 4 Anne, c. 16. These Statutes are part of the Law of Alberta by virtue of The Judicature Act. R.S.A. 1955, c. 164.

13 Prairie Oil \& Gas Co. v. Allen, 2 F. 2d 566 (1924).

1: Davis v. Byrd, 185 S.W. 2d 866 (1945), Earp v. Mid Continent Petroleum Corp., 27 P. 2d 855 (1933).

14 Supra, n. 10 at 179.

1s Williams and Meyers, Oil and Gas Law, Vol. 2, Sec. 502

16 Prairie Oil \& Gas Co. v. Allen, supra, n. 12.

1: [1944] 1 W.W.R. 691; (1944) 2 D.L.R. 74 (B.C.C.A.).
} 
ly and approvingly the words of Lord Cottenham in M'Mahon v. Burchell ${ }^{18}$ as follows:

Again, there are many cases where profits are made, and are actually taken, by one cotenant, and yet it is impossible to say that he has received more than comes to his just share. For instance, one tenant employs his capital and industry in cultivating the whole of a piece of land, the subject of the tenancy, in a mode in which the money and labour expended greatly exceed the value of the rent or compensation for the mere occupation of the land; in raising hops, for example, which is a very hazardous adventure. He takes the whole of the crops: and is he to be accountable for any of the profits in such a case, when it is clear that, if the speculation had been a losing one altogether, he could not have called for a moiety of the losses, as he would have been enabled to do had it been so culti. vated by the mutual agreement of the cotenants? The risk of the cultivation, and the profits and loss, are his own; and what is just with respect to the very uncertain and expensive crop of hops is just also with respect to all the produce of the land, the fructus industriales, which are raised by the capital and industry of the occupier, and would not exist without it. In taking all that produce he cannot be said to receive more than his just share and proportion to which he is entitled as a tenant in common. He receives in truth the return for his own labour and capital, to which his cotenant has no right.

This statement enunciates a concept well recognized in operating agreements most of which provide for a cash penalty payable by a party who does not wish to participate in drilling operations proposed by the other on jointly held lands. In exploratory well cases, some operating agreements go so far as to provide for forfeiture of acreage by the non-drilling party. While crude appeals as to what is usual in the industry are likely to fall upon deaf ears, ${ }^{19}$ yet there would appear to be some scope for claiming legal confirmation that he who takes the risk should get the spoils even in the face of counterargument that extraction of oil or gas involves a depleting and irreplaceable asset.

The above dissertation on items (1) and (2) assumes lack of an operating agreement between $\mathrm{A}$ and $\mathrm{B}$ containing a clause as follows:

\section{DISPOSITION OF PRODUCTION}

(a) Each of the Parties shall own its proportionate share of the Petroleum Substances produced from the Jointly Held Lands and shall, at its own expense, take in kind or separately dispose of its proportionate share of production exclusive of the production which may be used by the Operator in developing and producing operations and in preparing and treating oil for market purposes and of production unavoidably lost.

(b) To the extent that a Party entitled to take in kind any of the Petroleum Substances, fails to take or otherwise dispose of them at the time and place of production, then so long as such failure continues, the other Party, as agent and for the account and at the expense of said non-taking Party may sell, store, inject or otherwise dispose of them. Where there is a sale the net proceeds shall be paid to the non-taking Party. The other Party may contract for the sale thereof only for the minimum term obtainable which in no event shall exceed one year. When the other Party has so contracted, the non-taking Party may take its share of the Petroleum Substances in kind upon the expiration of the current sales contract.

Thus an obligation to take is imposed upon each party and the results in circumstances of failure to take are fairly clearly delineated.

We turn now to B's third course of action which is to make common purchaser application to the Oil and Gas Conservation Board. The

i* (1846) 2 Ph. 127 at $134 ; 41$ E.R. 889

ty Pine Pass Oil \& Gas Ltd. v. Pacific Petroleums Ltd. (1968) 70 D.L.R. (2d) 196 (B.C.S.C.). 
Oil and Gas Conservation Act ${ }^{20}$ provides that, upon application and after a hearing the Board with the approval of the Lieutenant Governor in Council, may declare any person who purchases, produces or otherwise acquires gas produced from a pool from which gas is being taken to be a common purchaser of gas from the pool. A common purchaser must purchase gas offered for sale to him without discrimination in favour of one producer or owner as against another in the pool. If after a declaration there are disputes as to point of delivery or amounts of gas to be taken from various producers the Board may resolve these by direction, but not so as to require a common purchaser to purchase a greater total amount of gas or to take gas at a greater rate than he was obligated to purchase or take under gas purchase contracts existing immediately prior to being declared a common purchaser. At a hearing for a common purchaser declaration the Board is interested in evidence as to past opportunities and future prospects for marketing of gas from the applicant's property and the extent to which drainage has occurred from the applicant's property subsequent to the completion of a well thereon. ${ }^{21}$

It appears that five applications have been made to the Board 22 and some were resolved by negotiation prior to hearing. In stating reasons for dismissing an application by Murphy Oil Company Ltd. relating to a spacing unit in the Carstairs field the Board in letter dated May 7, 1962 to all Operators stated:

Where no marketing opportunities have existed and where the prospects for marketing without the common purchaser declaration are not favourable, the Board would be sympathetic to an application made even at a time when a relatively small percentage of the reserves has been drained from the property. On the other hand, where marketing opportunities have recently existed, and where there are reasonable prospects for the marketing of the gas in the near future without the common purchaser declaration, the Board will be reluctant to make the declaration unless the drainage is more serious.

It is submitted that this statement of the Board's intentions is applicable to an assessment of present regulation $1401 .{ }^{23}$

The fact that $A$ and $B$ may be parties to an operating agreement containing a "take-in-kind" clause similar to that quoted above should not adversely affect B's rights in proper circumstances to obtain a common purchaser declaration. However, the existence of such a clause renders proceeding with an application unnecessary unless there are facilities whereby an injection operation can be carried out, or unless other producers in the pool are draining the lands owned by $\mathrm{A}$ and $\mathrm{B}$.

\section{Gas Market Sharing Schemes}

Rare is the market sharing scheme which meets both the demands of equity and the hopes of the co-producer who has the market sought to be shared. In the situation described above $A$ and $B$ were coowners in a spacing unit. Let us assume that the total reserves in the spacing unit are 10 bcf of gas of which $A$ has dedicated 5 bcf

20 Supra, n. 9, 8. 57.

21 Supra, n. 9, Regulation 1401.

22 Hebb, Common Carrier, Common Purchaser and Common Processor Orders, (1969) 7 Alta. L. Rev. 436 at $\mathbf{4 3 8}$.

23 For a discussion of the Murphy case and a subsequent application by McAlester Canadian Oil Co. with respect to a spacing unit in the Gilby Field, see Hebb, supra, n. 22 at 440-441. 
to the gas sales contract with $X .{ }^{24}$ The remaining 5 bcf belongs to $B$ and is not dedicated to any gas sales contract. $X$ is required to and does take delivery of 500 thousand cubic feet per day, the revenue of which A must share with B. Thus $5 \mathrm{bcf}$ of reserves are locked in for daily delivery purposes. $A$ and $B$ together thus occupy an inferior position vis-a-vis their competitors $\mathrm{C}$ and $\mathrm{D}$ in the pool who are allowed by the law to capture to produce and deliver to the full capacity of their reserves. It is thus to the advantage of both $A$ and $B$ to attempt to work out some equitable arrangement whereby their lands will not be drained and whereby they can receive full current revenue. Obviously $A$ and $B$ are not co-tenants with $C$ and $D$ and they cannot rely upon an action for an accounting. A has entered into a gas sales contract and in the eyes of the Conservation Board he has made his bed and must lie in it. The remedy is for $B$ to apply for a common purchaser declaration or, as stated, attempt to arrange a market sharing scheme with $C$ and $D$. In a case where $A$ and $B$ are not co-tenants in a spacing unit but $B$ is a sole lessee of a drilled spacing unit in the pool his remedies would be the same.

(a) Direction to Pay:

The simplest market sharing method is one whereby $A, C$ and $D$ agree with $B$ that $B$ is the owner of a certain percentage of the reserves in the pool and is thus entitled to receive that percentage of the total proceeds of the gas sales contracts which $A, C$ and $D$ have entered into with $X$. A, C and D undertake with $B$ to give and do give $\mathrm{X}$ directions to pay the proceeds in accordance with the arrangement. One case where this was accomplished involved a producer without a gas sales contract who owned an undivided percentage interest in all tracts in a proposed gas unit and in the wells thereon. It was impracticable, if not impossible, to unitize without the consent of that producer and the above arrangement was rapidly settled and unitization proceeded. The gas purchasing company raised no objections. The only difficulty, of course, was that the revenues of $A, C$ and $\mathrm{D}$ were decreased proportionately to make way for the revenues which were payable to $B$. But then as we have seen, $B$ would have been entitled to those revenues on an action for accounting.

(b) Long-Term Sharing:

Assume A, B, C and D each own an undivided $25 \%$ participating interest in a spacing unit upon which a gas well has been drilled and completed for production. $C$ and $D$ have entered into a gas sales contract with purchaser $Y$. A and $B$ have not entered into any gas sales contract but are hopeful of concluding one with purchaser $X$ at sometime in the future. One type of sharing arrangement might provide for the following:

(i) All gas produced from the well is to be produced and sold by the parties (C and D) having a market for same in the proportions of their participating interests (50-50). The gas owned by the nonselling parties (A and $B$ ) is to remain in the reservoir for produc-

24 For an analysis of gas purchase contracts including provisions as to minimum, maximum, daily and annual takes see Holland, Comparative Analysis of Gas Purchase Contracts, supra, at 479, Howell, Gas Purchase Contracts, 4th Oil and Gas Institute 151 (S.W. Leg. Fdn. 1953); Gregg. Negotiating and Drafting Gas Purchase Contracts on Behalf of the Seller, 13th Oil and Gas Institute 87 (S.W. Leg. Fdn. 1962) and Doggett, Marketing by Producer of Natural Gas Through Means-Conventional and Unconventional, Economics of the Gas Industry 193 (S.W. Leg. Fdn. 1962). 
tion at a later date. C and D become "over-produced" parties and A and B become "under-produced" parties;

(ii) When an under-produced party (A) becomes able to sell gas he is entitled to take a greater percentage of current production than his participating interest $(25 \%)$. Each over-produced party $(C$ and $D)$ will upon demand by under-produced party $A$ reduce its take in the proportion that the over-produced party's interest in cumulative over-production bears to the total volume of over-production. However, an over-produced party is not required to reduce his gas take entitlement to less than $75 \%$ (or in some agreements $50 \%$ or whatever is negotiated) of the over-produced party's interest in the total amounts nominated by gas purchasers $\mathrm{X}$ and $\mathrm{Y} ; 25$

(iii) When production permanently ceases an accounting occurs whereby the under-produced parties are paid by the over-produced parties sums of money equal to the amounts received, less taxes, by over-produced parties from sale of the total gas volumes produced to which the under-produced parties were entitled but which were actually sold by the over-produced parties. Where there have been gas sales price changes during the course of production, any temporary over-production by a party having an underproduction balance is credited to offset that under-production in the order of its accrual to the end that the party's under-production volumes are eliminated before the temporary over-production can be treated as over-production by any other party;

(iv) Royalty and operating costs are the responsibility of all parties irrespective of whether they are selling or not. The theory is that having to pay these amounts out of pocket will motivate nonselling parties to conclude gas sales arrangements and start producing.

One might wonder what advantage there is for $A$ and $B$ to enter into such an arrangement. An action for an accounting to the court or a common purchaser application to the Board or a simple reliance on the spacing unit operator to sell their gas under the operating agreement (if one exists) should be sufficient protection for $A$ and $B$ while they are searching for a market.

Some factors to be considered before entering into any long-term gas market sharing agreement are:

(i) What is the relationship between the owners of the lands which are subject to the arrangement? In the above example we have assumed that each holds an undivided interest in the entire spacing unit. If they owned separate interests in tracts in a pool they could not compel an accounting;

(ii) Forecasts of recoverable reserves and periodic redeterminations cannot be made with absolute accuracy. Accordingly, any scheme which allows one party to remove its reserves without a cash settlement on over-production being made periodically or upon

2s Some agreements refer to "current allowable," for example, the daily maximum allowable gas volume for the well under Regulation 925 of the Alberta Oil and Gas Conservation Regulations. However, in most situations the daily current allowable is far in excess of the daily volume nominated by the purchaser for delivery. Perhaps the solution is to refer to the lesser of the two. 
cessation of production is obviously fraught with dangers for the under-produced party; ${ }^{26}$

(iii) Cash balancing involves difficulties as to amounts payable by the over-produced party to the under-produced party. Consider a situation where the under-produced party has sold some gas at escalated prices towards the end of reservoir life. Under the arrangement described above these volumes sold extinguish his first underproduction volumes which were sold by the other party at low initial prices. On settlement he receives reimbursement for the remainder of his under-production volumes produced during the later life of the reservoir at the escalated prices received by the over-produced party. Thus it is conceivable that the under-produced party would receive a substantially higher sum of money on sales of his share of the gas reserves than did the over-produced party for his share. This objection might be dismissed on the ground that the under-produced party must wait for his revenue and thus on a discounted basis, monies received by each would be equalized. Most companies have a fetish for discounted cash flow calculations. Perhaps this is an instance in which several should be run on a number of variables;

(iv) If total cash received by each party is equal, as it will be if price escalations and production by the under-produced party reach the right mix, where is the equity in the deferment of payment for gas to the under-produced party when he is expected to bear out-of-pocket royalty and operating charges?

(v) Payment of the cash balance is, of course, dependent upon the financial solvency at some distant future of the prospective payor;

(vi) The position of the royalty owners and their relationships to the parties should be carefully examined before prospective underproduced parties undertake to satisfy royalty obligations;

(vii) Most gas-sharing arrangements do not include sharing of products markets. The agreement should make specific reference to the rights of all parties to take in kind their propane, butane, pentanes plus and sulphur.

(c) Short-Term Sharing:

In some instances the gas plant and the gathering system have been constructed and are ready to go on stream and the gas purchasing company has the right and wishes to take production from the field. The working interest owners, some of whom have wells on their tracts, are still engaged in a gradually subsiding squabble over unit participation, equalization of investment or other matters. The proposed unit operator is confident that unitization, will be accomplished within two or three months. He approaches the gas purchasing company or companies and attempts to make an arrangement under which, in the period between first delivery and the effective date of the unit, the producer will make full nominations as if the unit was in effect and pay proceeds to the proposed unit operator for distribution to the unit owners in accordance with their unit participations upon uniti-

${ }^{25}$ Baugh, “Gas Bank": Solution for Tough Unitization Problem, Oilweek, Sept. 30, (1963) at 29. 
zation becoming effective. Proposed parties should examine carefully the authorizing agreement to ascertain what the respective obligations of the parties to each other and to various royalty owners will be if no unitization or partial unitization occurs. The parties will have agreed to share gas sales on the basis of a unitization, which is not binding upon the royalty owners until the effective date of the unit and, prior to that date, only those royalty owners from whose lands gas is actually produced are entitled to royalty. One method of avoiding these difficulties is to draft a unit agreement which will, upon the occurrence of sufficient tract qualification become effective retroactive to the date of first gas delivery. ${ }^{27}$

Assume that gas deliveries are to commence June 1 and it is expected that unit documentation will be complete by September 1 so as to effect unitization retroactive to June 1 . An agreement can be entered into between the gas purchasing company and the working interest owners governing interim delivery of gas after date of first delivery (June 1) covering the following points:

(i) Deliveries of gas are scheduled to commence June 1 and all gas from the proposed unit area will be delivered pursuant to the gas sales contracts of the proposed unit participants in a common stream after processing in the gas processing plant;

(ii) The agreement will be effective from and after June 1 among the purchaser and such of the sellers under the gas sales contracts as execute and deliver the agreement by not later than July 1. Where more than one person constitutes a seller under a particular gas sales contract, the agreement only becomes effective with respect to that contract upon execution by all persons constituting the seller. Further, the agreement will not be effective unless all sellers owning spacing units upon which gas wells are located execute prior to June 20;

(iii) In lieu of nominating for gas under each of the gas sales contracts, the purchaser will nominate to the plant operator for total quantity to be delivered under all contracts. Also the plant operator is substituted for all sellers in rights and obligations under gas sales contracts with respect to quality tests and testing of measuring or testing equipment;

(iv) By not later than September 30 (by which time the unit likely, but not necessarily, will have become effective retroactive to the June 1 first gas delivery date) all sellers which are parties to the agreement by a written notice, unanimously assented to by all said sellers, are to advise the purchaser as to the ownership of all gas delivered or thereafter to be delivered from June 1 until the first day of the month next following the month in which the notice is served. If the sellers' notice is not given as above, all sellers which are parties to the agreement authorize and direct the plant operator forthwith after September 30 to notify the purchaser as to the ownership of all gas delivered from June 1 to October 1 . Upon receiving one or the other of the above notices the purchaser allocates to and pays the persons entitled in accordance with ownership as established by the notice. The agreement ceases to 
apply to gas deliveries from the area after the first day of the calendar month next following the month in which the sellers' notice was served or, if there was failure of said notice, October 1.

If unitization occurs as anticipated the sellers and the purchaser will enter a common stream arrangement substituting unit operator for each seller under the gas sales contracts with respect to rights and obligations covering nominations, quality testing, and providing for joint redetermination of reserves.

The effect of the above agreement covering interim gas sales is that if unitization does not occur as anticipated, the gas produced will be owned only by the sellers owning the spacing units and wells from which the gas was actually produced. All of these sellers are required to be parties to the agreement before the agreement can become effective. If unitization does occur retroactive to June 1 , the gas will be allocated in accordance with the unit agreement and ownership established accordingly. If some lands are not included in the unit, there will be no allocation to those lands if there is no well located thereon and the arrangement is thus a powerful inducement to sellers owning such lands to expedite the execution of the unit agreement. If lands upon which a well is located are not included in the unit then the seller owning those lands receives full ownership credit for gas produced and the remainder of the gas will be allocated in accordance with the unit agreement.

The proposed unit operator is usually the largest interest owner and likely would also be the plant operator pursuant to the plant agreement. By withholding execution of the unit agreement, he can block unitization if it appears that a significant number of sellers owning well spacing units will not execute the unit agreement. The obligation of the plant operator to give his notice "forthwith" after September 30 gives him a few days in which to make a final concerted effort to get an effective unit, although at some point a decision must be made to "fish or cut bait." Obviously, great confusion will occur if a notice is given by the sellers or the plant operator specifying ownership on a basis of non-unitization where the machinery of unit agreement execution grinds on so as to effect unitization retroactive to first gas delivery. Similarly, a specification of ownership on a basis of proposed unitization where no retroactive unitization occurs would also be unfortunate. The plant operator with a little experience and attention to detail should be able to orchestrate the matter.

Sellers may be concerned with granting the plant operator authority to give notice of ownership to the purchaser. However, the agreement does not allow the plant operator "absolute discretion," and presumably his decision would be subject to judicial review. If some difficulty did arise as to ownership of some gas volumes, he could specify those volumes in his notice to the purchaser and the purchaser could then interplead the disputing sellers' claims. Of course, the plant operator will have wellhead, gathering system, plant inlet and plant outlet meters.

Further, if the plant and gathering system construction and operating agreements have been prepared with foresight, the proposed working interest owners will be only too happy to execute the agreement covering interim gas sales, the alternative being no gas sales and 
ownership of an interest in facilities which, for them, will produce no cash return.

\section{Market Delay and Prepayment}

Assume that lessee producers each hold an undivided $50 \%$ interest in tracts of land in a gas pool. Assume further that:

(a) Total original recoverable reserves in place in tracts held by $\mathrm{A}$ and $B$ is 36.5 bcf.

(b) A has entered into a gas sales contract with purchaser $\mathrm{X}$ with deliveries to commence immediately, term 20 years, rate of take $1-7,300$ of A's share of reserves.

(c) $\mathrm{B}$ has entered into a gas sales contract with purchaser $\mathrm{Y}$ with deliveries to commence upon the granting of authorizations for export from Alberta and Canada and importation into the United States. The term is for 20 years from the date of first delivery of gas and the rate of take is the same as A's. Also $Y$ agrees to make prepayment for gas in the amount of $\$ 10,000$ per bcf of reserves committed upon execution of the contract and a further $\$ 10,000$ per bcf upon receipt of authority for export from Alberta. Prepayments are repayable to the purchaser by withholding one-third of the proceeds of sale commencing with first delivery until repaid.

Ignoring such factors as the usual $1 / 4 \mathbb{4}$ per mcf per annum price adjustment, reserve redeterminations during the life of the contracts, effects on discount factors of higher rates of take during the winter months, etc. the results of these arrangements would appear in simplified form in the following table.

During the first two Table Years lessee-producer B has chosen not to produce any gas. Lessee producer $\mathrm{A}$ produces and sells 1.825 bcf during those two years. Accordingly, .9125 bcf so produced and sold by $A$ is the property of $B$ and in respect of B's said gas $A$ has received $\$ 164,250$. As we have seen $B$ cannot obtain an injunction so as to prevent $A$ from producing gas. Based on our discussion of the rights of concurrent owners of gas produced, it would appear that $B$ could successfully demand an accounting from $A$ for the $\$ 164,250$, less his proportionate share of operating costs. A on the other hand would have difficulty in establishing any basis for an accounting to him for $\$ 182,500$ being $50 \%$ of the prepayment received by $B$ for the proposed sale of B's gas in subsequent years in circumstances where the sum received by $B$ is repayable. An action by $A$ for an accounting would be even more difficult where words of loan rather than prepayment are used to describe the transaction between $B$ and $Y$. At the other end of the term, we find B producing gas from the reservoir at a time when $\mathrm{Y}$ is no longer taking from $\mathrm{A}$. In fact, $50 \%$ of the gas so being produced and sold is the property of $A$ and A could successfully demand an accounting for $\$ 219,000$. The results of the parties so accounting one to the other are shown in the last two columns of the Table. However, $\mathrm{A}$ and $\mathrm{X}$ may agree to continue gas sales beyond the expiry of their initial contract term of 20 years. 


\begin{tabular}{|c|c|c|c|c|c|c|c|c|c|c|c|c|c|c|c|c|}
\hline \multirow[t]{2}{*}{$\begin{array}{l}\text { Table } \\
\text { Year }\end{array}$} & \multicolumn{2}{|c|}{$\begin{array}{l}\text { A.X Contract } \\
\text { Year and } \\
\text { Price in Cents } \\
\text { per mef }\end{array}$} & \multirow[t]{2}{*}{$\begin{array}{l}\text { Annual } \\
\text { Deliveries } \\
\text { A to } X \text { in } \\
\text { mmef }\end{array}$} & \multicolumn{2}{|c|}{$\begin{array}{l}\text { B.Y Contract } \\
\text { Year and } \\
\text { Price in Cents } \\
\text { per mcf }\end{array}$} & \multirow[t]{2}{*}{$\begin{array}{l}\text { Annual } \\
\text { Deliveries } \\
\text { B to } Y \text { in } \\
\text { mmef } \\
\\
0\end{array}$} & \multicolumn{2}{|c|}{$\begin{array}{l}\text { Annual } \\
\text { Payments } \\
\mathrm{X} \text { to A }\end{array}$} & \multicolumn{2}{|c|}{$\begin{array}{l}\text { Annual } \\
\text { Payments } \\
\text { Y to B }\end{array}$} & \multicolumn{2}{|c|}{$\begin{array}{l}\text { Cash Flow } \\
\text { to A dis. } \\
\text { counted at } \\
\text { 10r\%, to First } \\
\text { Payment } \\
\text { Date }\end{array}$} & \multicolumn{2}{|c|}{$\begin{array}{l}\text { Cash Flow } \\
\text { to B dis. } \\
\text { counted at } \\
\text { 105, to First } \\
\text { Payment } \\
\text { Date }\end{array}$} & $\begin{array}{l}\text { Cash Flow } \\
\text { to A dis- } \\
\text { counted at } \\
10 \text { with } \text { with } \\
\text { mutual } \\
\text { nccount. } \\
\text { ability for } \\
\text { first and } \\
\text { last two } \\
\text { Table Years }\end{array}$ & $\begin{array}{l}\text { Cash Flow } \\
\text { to B dis. } \\
\text { counted at } \\
\text { IOY, with } \\
\text { mutual } \\
\text { account. } \\
\text { ability for } \\
\text { first and } \\
\text { last two } \\
\text { Table Years }\end{array}$ \\
\hline & 1 & 18 & & & & & $\$$ & 164,250 & $\$$ & 182,500 & $\$$ & 155,709 & $\$$ & 182,500 & 77,855 & 260,355 \\
\hline 2 & 2 & 18 & 912.5 & & & 0 & & 164,250 & & 182,500 & & 140,927 & & 165,893 & 70,464 & 236,357 \\
\hline 3 & 3 & 18 & 912.5 & 1 & 18 & 912.5 & & 164,250 & & 109,500 & & 127,622 & & 85,081 & 127,622 & 85,081 \\
\hline 4 & 4 & 18 & 912.5 & 2 & 18 & 912.5 & & 164,250 & & 109,500 & & 115,468 & & 76,978 & 115,468 & 76,978 \\
\hline 5 & 5 & 18 & 912.5 & 3 & 18 & 912.5 & & 164,250 & & 109,500 & & 104,463 & & 69,642 & 104,463 & 69,642 \\
\hline 6 & 6 & 18 & 912.5 & 4 & 18 & 912.5 & & 164,250 & & 109,500 & & 94,608 & & 63,072 & 94,608 & 63,072 \\
\hline 7 & 7 & 21 & 912.5 & 5 & 21 & 912.5 & & 191,625 & & 127,750 & & 100,028 & & 66,686 & 100,028 & 66,686 \\
\hline 8 & 8 & 21 & 912.5 & 6 & 21 & 912.5 & & 191,625 & & 127,750 & & 90,447 & & 60,298 & 90,447 & 60,298 \\
\hline 9 & 9 & 21 & 912.5 & 7 & 21 & 912.5 & & 191,625 & & 173,375 & & 81,824 & & 74,031 & 81,824 & 74,031 \\
\hline 10 & 10 & 21 & 912.5 & 8 & 21 & 912.5 & & 191,625 & & 191,625 & & 74,158 & & 74,158 & 74,158 & 74,158 \\
\hline 11 & 11 & 21 & 912.5 & 9 & 21 & 912.5 & & 191,625 & & 191,625 & & 67,069 & & 67,069 & 67,069 & 67,069 \\
\hline 12 & 12 & 21 & 912.5 & 10 & 21 & 912.5 & & 191,625 & & 191,625 & & 60,745 & & 60,745 & 60,745 & 60,745 \\
\hline 13 & 13 & 21 & 912.5 & 11 & 21 & 912.5 & & 191,625 & & 191,625 & & 54,996 & & 54,996 & 54,996 & 54,996 \\
\hline 14 & 14 & 24 & 912.5 & 12 & 24 & 912.5 & & 219,000 & & 219,000 & & 56,940 & & 56,940 & 56,940 & 56,940 \\
\hline 15 & 15 & 24 & 912.5 & 13 & 24 & 912.5 & & 219,000 & & 219,000 & & 51,465 & & 51,465 & 51,465 & 51,465 \\
\hline 16 & 16 & 24 & 912.5 & 14 & 24 & 912.5 & & 219,000 & & 219,000 & & 46,647 & & 46,647 & 46,647 & 46,647 \\
\hline 17 & 17 & 24 & 912.5 & 15 & 24 & 912.5 & & 219,000 & & 219,000 & & 42,267 & & 42,267 & 42,267 & 42,267 \\
\hline 18 & 18 & 24 & 912.5 & 16 & 24 & 912.5 & & 219,000 & & 219,000 & & 38,106 & & 38,106 & 38,106 & 38,106 \\
\hline 19 & 19 & 24 & 912.5 & 17 & 24 & 912.5 & & 219,000 & & 219,000 & & 34,602 & & 34,602 & 34,602 & 34,602 \\
\hline 20 & 20 & 24 & 912.5 & 18 & 24 & 912.5 & & 219,000 & & 219,000 & & 31,317 & & 31,317 & 31,317 & 31,317 \\
\hline 21 & & & 0 & 19 & 24 & 912.5 & & & & 219,000 & & & & 28,251 & 14,125 & 14,125 \\
\hline 22 & & & 0 & 20 & 24 & 912.5 & & & & 219,000 & & & & 25,623 & 12,812 & 12,812 \\
\hline & Tot & & $18,250.0$ & & & $18,250.0$ & & 859,875 & & $, 115,375$ & & 569,408 & & $, 456,367$ & $\$ 1,448,026$ & $\$ 1,577,749$ \\
\hline
\end{tabular}

*Prepayment to $\mathrm{B}$ as $\$ 10,000$ per bef for reserves committed is made at the beginning of Table Year 1 with further prepayment at the beginning of Table Year 2. Recovery of prepayment in the third Table Year is at the rate of one-third gross gas sales proceeds and net proceeds and net proceeds after deduction of repayment are shown in the third and following calendar years until completion of repayment. Discount factors for first and second Table Year payments to B are 1.000 and .909 respectively because the money is payable in lump sums at the beginning of the first and second Table Years. Discount factors for the first and second Table Year payments to $A$ are .948 and .858 . 
In such case $A$ and $B$ can each deliver 912.5 mmct to $X$ and $Y$ respectively without having to account one to the other. The effect for $Y$ is that he will, on reservoir depletion, have purchased 912.5 mmcf less than $X$.

\section{VARIATIONS IN RESERVE DETERMINATION, PRICES, RATE OF TAKE AND SPECIFICATIONS}

\section{1. "Stacked" Gas Sales}

This form of sale is introduced as an illustration of reserves determination and other problems and their resolution. In an area where a portion of the lands are owned in undivided interests by some producers and other lands are wholly owned or owned in undivided interests by other producers the gas sales history might be as follows:

\begin{tabular}{|c|c|c|c|}
\hline \multirow{3}{*}{$\begin{array}{c}\mathrm{G} \\
\text { to } \\
\mathrm{Y} \\
50 \\
\text { bcf }\end{array}$} & \multirow{3}{*}{$\begin{array}{c}\mathbf{E} \& \mathbf{F} \\
\text { to } \\
\mathbf{X} \\
50 \\
\text { bcf }\end{array}$} & $\begin{array}{l}\text { A B C \& D to Y } \\
\text { Excess up to } \\
100 \text { bcf }\end{array}$ & 4 \\
\hline & & $\begin{array}{l}\text { A B C \& D to X } \\
100 \text { bcf }\end{array}$ & 3 \\
\hline & & $\begin{array}{l}\text { A B C \& D } \\
\text { to } Y \\
300 \text { bcf }\end{array}$ & 2 \\
\hline 6 & 5 & $\begin{array}{l}\text { A B C \& D } \\
\text { to } X \\
400 \text { bcf }\end{array}$ & 1 \\
\hline
\end{tabular}

The six gas sales contracts are numbered in the order of 1 to 6 in the above diagram indicating the order of the effective date of each. The original unit area comprised lands covered by contracts 1 to 4 and the unit area was subsequently enlarged to include lands under contracts 5 and 6 . Immediately upon execution of contracts 1 and 2 , A, B, C, D, X and Y agreed that joint studies would be conducted for the determination of total original reserves in place in lands covered by the contracts and failing an agreed determination, to determine the same by arbitration. Subsequent agreement would incorporate contract 3 into the arrangement, contract 4 being immaterial to $X$. These joint determinations are necessary in that the rights to purchase gas under contracts 1 to 4 are in the priority of the dates of the gas sales contracts. Thus, if it subsequently appears that original reserves were $750 \mathrm{bcf}, \mathrm{X}$ is entitled to purchase full reserves on contract 1 and one-half reserves on contract 3 and $\mathrm{Y}$ is entitled to 
purchase full reserves on contract 2 and no reserves on contract 4 . The entry into the picture of producers $E, F$ and $G$ on unit enlargement requires further agreement. Sellers A, B, C, D, E and F would agree with $\mathrm{X}$ that:

(a) Unit operator $A$ will notify $X$ of aggregate unit contract participations from time to time applicable to lands dedicated to contract 5 and of original recoverable reserves of gas from time to time determined pursuant to contracts 4 and 6 , of which $X$ otherwise would have no knowledge because these are $Y$ contracts not subject to joint reserve studies;

(b) Monthly gas volume delivered by $\mathrm{E}$ and $\mathrm{F}$ to $\mathrm{X}$ is determined by multiplying the sum of all gas delivered to $X$ from the unit plus all gas delivered to $\mathrm{Y}$ from the unit in the month by the $\mathrm{E}$ and $\mathrm{F}$ unit tract participations notified to $\mathrm{X}$ by $\mathrm{A}$ under (a) above;

(c) Total volume of gas delivered by A, B, C and D to $\mathrm{X}$ is determined by subtracting $E$ and $F$ volume determination in (b) from total volume delivered to $\mathrm{X}$ from the unit;

(d) Similar calculations are made by dividing $\mathrm{E}$ and $\mathrm{F}$ original reserves and unit reserves less $E$ and $F$ reserves by 7,300 or 8,400 or 10,000 or whatever is applicable to establish minimum take or pay for obligations to $E$ and $F$, on the one hand, and $A, B, C$ and $D$ on the other hand. $X$ is deemed to have complied with its minimum take or pay for obligations in any year in which it has taken its total minimum daily quantities. If in any year $X$ is entitled to receive makeup gas (gas for which prepayment has been made in a previous year) under any gas sales contract, then after $\mathrm{X}$ has complied with its minimum take obligations for the year and until $\mathrm{X}$ has received the make-up gas it is entitled to receive under the contracts for the year, all gas delivered to $\mathrm{X}$ is apportioned by $\mathrm{X}$ to contracts 1,3 and 5 as $\mathrm{X}$ may in its absolute discretion determine.

A, B, C, D and G will enter into a somewhat similar agreement with Y.

\section{Price Variations}

Because most gas reserves are unitized we will deal here with effects of differing prices paid to different sellers by separate purchasers in a voluntary unitization situation. ${ }^{28}$ The reader can judge whether the following discussion applies to cases of voluntary pooling pursuant to various forms of pooling agreements or to cases of compulsory pooling pursuant to Section 82 or 83 of The Oil and Gas Conservation Act, 1969.

The Model Oil and Gas Unit Agreement, ${ }^{29}$ modified for each individual case, is the basis from which drafting of most unit agreements proceeds. It provides in part:

\footnotetext{
23ecs. 87 to 95 of The Oil and Gas Conservation Act not having been proclaimed, there is no compulsory unitization in Alberta.

2 The clauses quoted are from the Model, including 1968 amendments, approved by the Petroleum and Natural Gas Committee of the Mines Ministers Conference. The approval is as to form only with the intention that the model form will be used as a guide. Its use has been a factor in expediting unitization by eliminating unnecessary dialogue over points of legal form.
} 
306. Effect of Unitization on Titles

Nothing herein shall be construed as a transfer or exchange of any interest in the Leases, Tracts or Unitized Zone, or in the Unitized Substances before production thereof.

\section{Allocation to Tracts}

Subject to clauses 801 and 802 [dealing with use, loss or storage] the Unitized Substances when produced shall be allocated to the Tracts in accordance with their Tract Participations. The amount of Unitized Substances allocated to each Tract, and only that amount, regardless of whether it be more or less than the amount of actual production of Unitized Substances from the well or wells, if any, on the Tract, shall be deemed conclusively to have been produced from the Tract.

\section{Distribution Within Tracts}

The Unitized Substances allocated to a Tract shall be distributed by the Working Interest Owners thereof among, or accounted for to, the Parties entitled to share in production from the Tract in the same manner, the same proportions, and upon the same conditions as they would have participated and shared in the production from the Tract, or in the proceeds from the sale thereof, had the Unitized Substances allocated to the Tract been actually produced therefrom by the Working Interest Owners.

\section{Calculation of Royalty}

The Working Interest Owners of each Tract shall calculate royalty on the Unitized Substances allocated to the Tract at the applicable rate under the Lease, other agreement or instrument relating to the Tract. The Royalty Owners of each Tract agree to accept payment of royalty so calculated in satisfaction of the obligation of a Working Interest Owner to make royalty payments on Unitized Substances under the Lease of such Tract; ... . .

In Shell Oil Company v. Corporation Commission of Oklahoma, the Commission, the Oklahoma equivalent of the Oil and Gas Conservation Board, established 640 acre drilling and spacing units and ordered "that all royalty interests within any spacing unit shall be communitized and each royalty owner within any unit shall participate in the royalty from the well drilled thereon in the relation that the acreage owned by him bears to the total acreage in the unit." 30

In the litigated spacing unit 320 acres were under lease from A to Shell and the other 320 acres were under lease from B to Sun. Shell and Sun drilled a gas well. Shell entered into a gas sales contract to sell gas to $X$ at a basic price of 154 per mcf and Sun entered into a gas sales contract with $\mathrm{Y}$ at a basic price of $17 \AA$ per mcf. $\mathrm{X}$ began taking gas from Shell immediately and it was contemplated that when Sun's purchaser Y made a pipeline connection, Sun would "catch up" with Shell. Shell paid royalty to A and kept in its possession the money it received from the sale of gas apportionable to Sun's lessor B. Sun made no royalty payments to B. B demanded royalty from Sun and receiving no satisfaction applied to the Commission for an interpretation of the order. The Commission stated that in entering the said order it contemplated that current production from the well or wells on each producing drilling and spacing unit would be divided volumetrically, that the respective volumes of such production would be currently allocated to the separately owned tracts or interests on an acreage basis, and that the production so allocated would be treated for all purposes, including payment of royalties, as if it were actually produced from such separately owned tract or interest by a well drilled thereon. The Commission thus adopted a "tract allocation" type of royalty interest communitization. 
The matter then proceeded to the Supreme Court of Oklahoma, where Shell contended that the Commission ruling was contrary to the "royalty provisions" of the Oklahoma statute," which, in essence provided as follows: (Identifying numbers added.)

1. The portion of the production allocated to the owner of each tract in a well spacing unit formed by a pooling order shall, when produced, be considered as if produced by such owner from the separately owned tract or interest by a well drilled thereon.

2. The owner of oil and gas rights in an unleased tract shall be regarded as a lessee to the extent of a seven-eights interest in said rights and a lessor to the extent of the remaining one-eighth interest therein. 3. If a producing well is completed upon a unit where there are two or more separately owned tracts, any royalty owner holding the royalty interest under a separately owned tract included in such spacing unit shall share in one-eighth of all production from the well or wells drilled within the unit in the proportion that the acreage of the separately owned tract bears to the entire acreage of the unit;

4. Where a lease covering any such separately owned tract included within a spacing unit stipulates a royalty in excess of one-eighth of the production, or said lease shall be subject to an overriding royalty, to production payment or other obligation, then the lessee of said lease out of his share of the working interests from the well drilled on said unit, shall pay said excess royalty, overriding royalty, or production payment.

To summarize the Court's analysis of these provisions: paragraph 2 makes a distinction between owners of the working interests and owners of the royalty interests. Under paragraph 1 production from $7 / 8$ working interest is allocated to the lessees and considered as if produced by the lessee from his separately owned tract by a well drilled thereon. Thus, as to the $7 / 8$ working interest, production is allocated on a "tract allocation" basis. However, under paragraph 3 any royalty owner shares in $1 / 8$ of all production from the well in the proportion that his acreage bears to total unit acreage. Royalty so allocated to the lessor is not considered as if produced on the lessor's acreage by a well drilled thereon. The $1 / 8$ royalty is to be shared by each royalty owner in the ratio that his acreage bears to total unit acreage. Paragraph 4 provides a different method of responsibility for payment of overriding royalties, production payments, etc. these responsibilities being placed upon the lessee owning a lease burdened with such obligations to pay them out of the production from his working interest in the well.

The result was that on wellhead gas sales, sold by Shell at the rate of 154 per mcf, Shell had to pay each lessor in the spacing unit on the proceeds at 154 per mcf. If Sun sold gas at $17 \AA$ per mcf it had to pay each lessor on the proceeds at $17 \uparrow$ per mcf and "when Sun and Shell are both taking simultaneously from the well each should account to the royalty owners at the rate which each lessee receives for the sale of gas disposed by it."

Payments to royalty owners in Alberta units do not conform to the above principles. The model form of unit agreement makes no distinction between $7 / 8$ working interest and $1 / 8$ royalty interest on unleased

if 52 O. S. 1961, Sec. 871 (d). 
fee simple lands. ${ }^{32}$ Allocation of production is made to unit tracts and not to owners whereupon the allocated production is deemed to have been produced from the tract. Nowhere is there provision for sharing by royalty owners in production of unit wells and by definition no distinction is made between lessor royalty owners and gross overriding royalty owners, both being categorized as "Royalty Owners". Accordingly, the facts and law upon which the Oklahoma Court based its decision are not applicable in Alberta and it is submitted that the Alberta practice is correct. ${ }^{33}$ The practice is that royalty is paid by each lessee with respect to gas allocated to a tract only to the royalty owner lessor of that tract calculated on sales price pursuant to the gas sales contract covering that tract. No tract in any properly drafted unit agreement covers lands which are subject to more than one lease. There is no suggestion in the Shell case that a lessee in Oklahoma could claim receipt of proceeds on a weighted average basis following pooling and it is submitted that no Alberta lessee could successfully so claim following either unitization or compulsory pooling.

\section{Rates of Take and Original Reserves}

So far we have been following a moderately discernable trail of precedent but we now enter into an "almost tractless wilderness of gas producerdum". ${ }^{34}$ The past decade has seen a great expansion in the gas production industry. The efforts of all concerned have been directed towards expediting the production and sale of gas. There has been an almost overwhelming myriad of detail involving export authorizations; pipeline, gas plant and field and gathering system construction; unitization; exploration and development, etc. The original reserves of fields have been continuously revised upwards. Concerns about problems which might occur on field depletion are considered irrelevant, if not frivolous.

Suppose a unit consisting of four tracts in which each working interest owner owns a tract having $25 \%$ of the unit participation. $A$ and $B$ have entered into gas sales contracts with $X$ under each of which $\mathrm{X}$ recognizes 50 bcf of original gas reserves and is obligated daily to take or pay for $1 / 10,000$ of reserves with price escalating from 154 per mcf. $C$ and $D$ have entered into contracts with $Y$ under each of which $Y$ recognizes 60 bcf of original gas reserves and is obligated to take or pay for daily $1 / 8,400$ of reserves with price escalating from $17 \$$ per mcf.

Suppose that in a given month purchaser $Y$ takes 420 mmcf of gas by nomination to unit operator under its common stream arrangement while $X$ takes 300 mmcf of gas by similar nomination. The unit produces $720 \mathrm{mmcf}$ (actually more due to gas processing shrinkage) and each of the four tracts is allocated $180 \mathrm{mmcf}$ pursuant to the unit agreement. Thus each of $\mathrm{A}, \mathrm{B}, \mathrm{C}$ and $\mathrm{D}$ are owners of $180 \mathrm{mmcf}$ which has been delivered to $\mathrm{X}$ and $\mathrm{Y}$ in the amounts set out above.

32 A provision making such a distinction modelled on what is now Section 1.7 of the API model form of unit agreement was dropped from the Mines Ministers Model some years ago. The conclusion reached was that its only effect could be to relieve a defaulting fee simple interest owner from seizure and sale of $8 / 8$ of his production on failure to pay his share of operating costs.

33 See Arkansas Louisiana Gas Co. v. Southwestern Natural Prod. Co. 60 So. 2d 9; 1 O. \& G. R. 1186 (1952); State ex Rel. Superior Oil v. Texas Gas Transmission Corp., 136 So. 2d 55; 16 O. \& G. R. 582 (1961). See also Ellis, The Production of Gas from Joint Interest Properties, 21st Oil and Gas Institute 47 (S.W. Leg. Fdn. 1970).

34 Hillyer, Problems in Producing and Selling, by Split or Single Stream, Gas Allocable to Diverse Working Interest Ownerships, 16th Oil and Gas Institute 243 (S.W. Leg. Fdn. 1965). 
What has happened is that $\mathrm{Y}$, which has no contractual relationship with $A$ and $B$, has received from the unit operator $30 \mathrm{mmcf}$ from each of $A$ and $B$. $Y$ has knowingly received the gas, the property of $A$ and $B$, and if $Y$ pays $C$ and $D$ for the gas it is making payment therefor to persons not entitled to receive payment. ${ }^{35}$ What happens in practice is that $\mathrm{Y}$ does pay $\mathrm{C}$ and $\mathrm{D}$ for the gas owned by $\mathrm{A}$ and $\mathrm{B}$ and the unit operator, the other producers and the gas purchasing companies keep a close watch on developing imbalances. Over a period of time, sometimes as long as three or four years, these imbalances are corrected by $\mathrm{X}$ increasing his nominations. Further it is hoped, as production data accumulates over the life of the field, that the divergent reserve estimates of the purchasing companies will be equalized and thus made to conform with those of the producers and royalty owners as evidenced by the tract participations. Further, each purchasing company will be concerned to recover reserves under lands committed to its contract and will not allow a large imbalance to develop. In our case Y's minimum takes exceed X's maximum takes so that an early upward reserve redetermination at X's urging can be expected. Nevertheless, it is conceivable that a large imbalance could exist on reservoir depletion. At that time the producers which find themselves in a credit position would undoubtedly take action to recover from the other producers, and possibly from the gas purchaser which took delivery of their gas volumes, the value of the "credit" gas. In the meantime, under present practice, the royalty owner waits unless he also has royalty interests in tracts owned by producers accumulating "debit" gas. Technically, during periods of imbalance the leases of the "credit" owners are in default as to royalty obligations.

It might be thought that such problems would be easily resolved if the unit agreement provided for periodic adjustment of tract participations based on reserve redetermination rather than, as is usual, for tract participations to remain in fixed ratios one to the other for the life of the unit. I submit that such a solution would beget more problems than it would solve. Even where one purchaser only is in the field, the unit operator will be subjected to abnormal scrutiny and suspicion as to well locations, method of operating wells, etc., and the gas purchasing company will find it abnormally difficult to come to agreement with producers on reserve redeterminations. With two purchasers, each dealing with a different set of producers, the situation would be extremely difficult.

\section{Specification Variations}

Differences in specification standards for sales gas as between different purchasers are rather easily resolved. Starting from the premise that every producer must deliver "on-spec" gas to his purchaser the processing plant is constructed accordingly. Where there are differences in specifications of raw gas delivered to the plant, plant construction and operating charges can be adjusted so that those parties delivering the sourest gas pay a disproportionately higher amount of cost of equipment necessary to render the gas marketable. Similarly, parties can be penalized should extra plant equipment be necessary to enable those parties to meet the peculiar standards of their purchaser. Such specifications problems as did exist are now almost

3s See Hillyer, supra, n. 34 at 259. 
completely resolved by the two straddle plants, one on the TansCanada stream moving east and south and the other on the AlbertaSouthern stream moving west and south. Any substances which might give difficulty to ultimate customers are removable in those plants.

\section{E. THE ROYALTY OWNER}

Lurking (or sleeping) in the shadows is the oft-forgotten royalty owner. He has leased his gas rights to one or other of the producers. Aside from frequently successful attempts by the royalty owners to cancel leases, conflicts between royalty owners and producers in the gas industry usually involve processing and gathering charge deductions from plant outlet sales prices of residue gas and products so as to arrive at a just and reasonable wellhead price on which to pay royalty. We will consider two other questions of royalty owner-producer concern. What effect have prepayment arrangements on the lessor-lessee relationship? What right does the royalty owner have to require that royalty shall be paid, not on the proceeds received by the producer from the purchaser but rather on a current market value of the product?

\section{Prepayments}

Producer $B$, after some negotiation with purchasers $\mathrm{X}$ and $\mathrm{Y}$, has rejected X's offer to buy gas with deliveries to commence immediately. $B$ enters into a gas sales contract with $Y$ containing a clause as follows:

Y shall, upon execution, pay B $\$ 5,000$ per billion cubic feet of recoverable gas reserves attributable to $B$ 's interest in the field. Further $Y$ shall, upon the Oil and Gas Conservation Board authorizing the sale of gas from the field, pay $B \$ 10,000$ per billion cubic feet of recoverable gas reserves so authorized for sale. After $\mathrm{Y}$ commences taking delivery of gas hereunder, $Y$ shall be entitled to recoupment of all prepayments by withholding $50 \%$ of the proceeds due B for gas delivered to $\mathrm{Y}$ hereunder. If, prior to April 1, 1973, $Y$ is unable to take gas by reason of lack of authorization of any governmental authority, this Agreement shall terminate and $B$ shall forthwith repay to $Y$ all prepayments hereunder. ${ }^{36}$

Let us also assume that $B$ holds its rights to the gas, which is the subject of the gas sales contract, under a freehold lease whereby the lessor has reserved royalty in the following manner:

The Lessee shall pay to the Lessor as royalty one-eighth of the current market value at the well of gas produced from the said lands and marketed or used off the said lands. ${ }^{37}$

The royalty owner-lessor may claim for a royalty share of amounts paid to the producer as prepayment for gas not yet physically taken out of the ground. He will have to establish that the word "produced" as used in the lease refers to amounts of gas that the well is capable of producing and that calculation of royalty is not restricted to circumstances where gas is actually produced.

In the circumstances here it is possible that the lessee will have availed himself of the lease shut-in well clause which might read as follows:

SHUT.IN WELLS. If at any time all wells on the said lands or on lands with which the said lands are pooled or unitized, are, either before or after production of leased substances has been obtained therefrom, shut-in, suspended, capped or otherwise are not being produced, as the result of a lack of or an intermittent

\footnotetext{
36 In event of termination, some contracts provide for repayment out of future gas sales to third persons.

${ }^{37}$ Royalty clauses in freehold leases come in a variety of forms. This form is very common.
} 
market or any cause whatsoever beyond the Lessee's reasonable control, the Lessee may pay or tender to the Lessor within sixty (60) days after the date of such wells being shut-in, suspended, capped or otherwise not being produced, a royalty payment equal to the amount of the delay rental provided for in this lease, to cover the period from the date such wells are shut-in, suspended, capped or otherwise not being produced to the next anniversary date of this lease. Further, the Lessee may pay or tender to the Lessor within sixty (60) days after the said next anniversary date and each successive anniversary date thereafter of this lease a royalty payment equal to the amount of the delay rental provided for in this lease, each said payment to cover the period from the anniversary date within sixty (60) days of which said payment was paid or tendered to the next succeeding anniversary date. As often as such payments or tenders are made it shall be considered under all provisions of this lease that leased substances are being produced from the said lands during the entire period for which such royalty is paid or tendered. ${ }^{38}$

A court might accept that "under all provisions" of this lease or "for all purposes" of the lease there is production. Further, there is the delicate question as to whether the effectiveness of the shut-in clause to maintain the lease in effect is vitiated in circumstances where the lessee has chosen a delay-delivery purchaser over an immediate-delivery purchaser. The grounds for such a contention are that shut-in payments may only be made, according to most lease forms, where the wells are shut in as the result of a lack of or an intermittent market or any cause beyond the lessee's reasonable control.

The royalty clause provides for payment of royalty on "current market value" where there is production and sale. Assuming production has been established by the operation of the shut-in well clause, the lessee would be hard put to deny a sale in the face of evidence as to a gas sales contract in more or less the usual form and the deposit of large sums of gas prepayment money in the lessee's bank account. If the prepayment was only repayable out of future proceeds under the gas sales contract, then one might conclude that the royalty share of the prepayment should be paid immediately to the lessor. Of course, during the years of gas production in which the prepayment is being repaid the lessor's royalty would be reduced by his share of the repayment. However, there is an element of uncertainty introduced by the provision as to repayment in the event of early termination of the gas sales contract for lack of governmental authorization for export or import. Obviously, the lessee would be loath to pay over $1 / 8$ of this substantial sum and then be faced with a claim by the purchaser for the entire amount of prepayment upon an early termination. Perhaps the rewarding areas of implied contract, constructive trust, unjust enrichment and fiduciary relationship would provide a royalty owner with some kind of claim. These subjects were rather extensively analyzed in the papers presented at the Canadian Petroleum Law Foundation First Annual Research Seminar in Oil and Gas Law. ${ }^{39}$

Some views as to the nature of the lessor-lessee relationship are:

Looking beyond the mere language of our decisions and considering the grounds relied upon to justify the implication of these covenants, it seems to the writer that the implication is viewed as one of fact and not of law. It will be observed that all of these implied covenants are directed towards one end: the protection of the royalty interest of the lessor ... . The emphasis is entirely upon the fact

\footnotetext{
as Another form might refer to a specified payment for each shut-in well and then may use the phrase "each such well shall for all purposes hereof be deemed to be a producing well hereunder."

39 Bredin. Types of Relationship Arising in Oil and Gas Agreements, (1964) 3 Alta. L. Rev. 333; Ballem, The Scope of the Fiduciary Relationship. (1964) 3 Alta. L. Rev. 349 and Muir, Duties Arising Outside of the Fiduciary Relationship, (1964) 3 Alta. L. Rev. 359.
} 
that a royalty is reserved, and the theory of the courts seems to be that the creation of a royalty, the payment of which is to be governed by the amount of production, is enough, standing alone, to justify the implication of any reasonable obligation looking to its protection. This implication is based upon the thought that the prospective royalties constitute one of the primary inducements for the execution of the lease, and, since the lease makes the payment of this compensation to the lessor dependent upon the diligence and care with which operations are conducted by the lessee, the parties must have intended that these operations would be conducted with a reasonable regard for the interests of the lessor and not solely from the selfish standpoint of the lessee. If this is a correct interpretation of the theory of our cases the implication of these covenants is predicated upon the intention of the parties and is one of fact and not of law. ${ }^{40}$

The parties have not agreed consciously upon the terms which the law implies; it is even possible that they have never consciously directed their attention to the matter. The obligations are imposed, not by the agreement of the parties, but by operation of law. ${ }^{11}$

Is not the real basis of the doctrine of implied covenants in oil and gas leases to be found in a theory of enforcing that conduct which, under the circumstances, fair dealing between lessor and lessee fairly demands that the latter pursue? Do not the conditions which have been reviewed justify the judicial imposition of that standard of conduct upon the lessee?42

The implication of any reasonable obligation looking to the protection of the royalty interest would, I submit, impose an obligation on the lessee to hold in trust for the lessor his royalty share of the prepayment until the occurrence of the conditions precedent (government authorization), upon which, the royalty share would be payable to the lessor. A basic principle of the law of trusts is that a trustee cannot make a profit for himself out of the trust without the knowledge and consent of the cestui que trust. Accordingly, any short-term money market interest or other return on the money held by the lessee would have to be accounted for to the lessor.

Though implication of production through shut-in well payments would ease the royalty owner's task, there might be sufficient grounds for a claim of royalty on prepayment in the absence of such payments. These grounds, based on equitable concepts of "fair dealing" or "reasonable regard for the interests of the lessor", are to be found in the above-described rewarding areas of implied contract, constructive trust, unjust enrichment and fiduciary relationship. In Butler v. Jenkins Oil Corporation, ${ }^{43}$ the appellant Butler had assigned an interest in an oil and gas lease to the respondent Jenkins and contemporaneously received back an assignment of the lease containing the following provisions:44

....insofar as it covers a one-sixteenth overriding royalty out of the leaseholder's seven-eighths, said one-sixteenth overriding royalty to cover the oil, gas and other minerals in and under all of the above described thirty acre tract of land, more or less, to be paid on such basis as long as each well upon said lease produces one hundred ninety barrels, or more per day, to be based upon an average of fifteen days.

In the event said well or wells produce less than one hundred ninety barrels per day each to be based an average of fifteen days then said overriding royalty shall be one thirty-second interest, the above royalty interest to be computed on each well separately.

Butler contended that at the time the assignment was executed the

40 A. W. Walker, Jr., The Nature of the Property Interests Created by an Oil and Gas Lease in Texas, (1933) 11 Texas L. Rev. 399 at 404.

1 Merrill, Covenants Implied in Oil and Gas Leases at 27 (1940).

42 Id. at 469.

${ }^{43} 68$ S. W. $2 d 248$ (1934); aff'd, 97 S. W. $2 d 466$.

"Id., 68 S. W. $2 \mathrm{~d}$ at 249. 
parties had discussed, had in mind and intended to use the word "produces" as mecning the amount the well could or had the capacity to produce. Jenkins contended that the terms of the assignment were unambiguous and properly construed and in the absence of fraud, accident or mistake, did provide that the royalty interest was determined by the amount of oil and gas actually produced from each well computed separately. The court concluded that had Jenkins failed to fully equip the wells for production, Butler could plead that but for such failure the wells could and would each have actually produced 190 barrels or more per day during the required period of time. However, in the absence of some hindering cause for which Jenkins would be responsible, the term "produce" must be given its ordinary meaning. ${ }^{45}$

If the circumstances here were that two alternative markets were available, one to purchaser $Y$ with delayed delivery, but on a prepayment basis, and the other to purchaser $X$ who was willing to take gas immediately, but at a lower price, then the lessor might allege that the action of the lessee was "a hindering cause" of failure to produce or, in other words, a failure to perform an implied covenant to market the product with the diligence of a prudent operator. Further, where two such alternatives face the producer, it is submitted that attack by the royalty owner on the grounds that the producer has not acted diligently, prudently or in accordance with a possible implied covenant to market might succeed. ${ }^{46}$ It has been said that: ${ }^{47}$

The greatest possible leeway should be indulged the lessee in his decisions about marketing gas, assuming no conflict of interest between lessor and lessee. Ordinarily, the interests of the lessor and the lessee will coincide; the lessee will have everything to gain and nothing to lose by selling the product. Where the interests of the two diverge and the lessee lacks incentive to market gas, closer supervision of his business judgment will be necessary.

Where the two alternatives described were available a conflict of interest certainly existed. The lessee has had his cake and eaten it too. He has chosen the purchaser who will pay the highest ultimate price and he has avoided the inconvenience of delay delivery by obtaining present revenue. The choice, however, is not likely to appeal to the royalty owner. The argument that he is going to get his money eventually when all conditions precedent to the obligations of the purchaser to take gas are fulfilled is not likely to satisfy him. He may wonder if the conditions may ever be fulfilled or whether he is prejudicing some future claim by continuing to accept shut-in royalty payments. ${ }^{48}$

At this juncture we refer to the papers presented at the First Sem-

45 There is a series of cases dealing with the use of the word "produce" in the habendum clause of leases namely: Fick v. Wilson, 349 S. W. 2d 622; 15 O. \& G. R. 520 (1961); Garcia v. King, 164 S. W. 2d 509 (1942); Gypsy Oil Co. v. Marsh, 248 Pac. 329 (1926); Berthelote v. Loy Oil Co., 28 P. 2d 187 (1933) and Benedum-Trees Oil Co. v. Davis 107 F. 2d 981 (1939). The normal construction of the word "produce" as used in the habendum clause providing that the lease shall be for a term of ten years and so long thereafter as oil or gas is produced from the leased land is synonymous with the words "produce in paying quantities," that is, production in quantities sufficient to yield a return in excess of operating costs.

«s The only two Canadian oil and gas cases dealing with implied covenants are Docker v. London-Elgin Oil Co. (1908) 11 O.W.R. 726 and Reynolds v. Ackerman (1953) 32 W.W.R. (N. S.) 289. These cases dealt with implication of development covenants.

47 Williams and Meyers, supra, n. 15, Vol. 5, Sec. 856. 3, at p. 410.1.

48 In Grazin v. Pan American Petroleum Corporation, 317 P. 2d 1010 (1962) it was held that acceptance of delay rentals after completion of a shut-in gas well bars enforcement of the implied covenant to use due diligence to market the product during the period for which rentals are accepted and that such period is excluded in calculating the reasonable time within which the lessee must market. However, Williams and Meyers, supra, n. 47, Sec. 858.1 thoroughly analyze the decision and conclude that it is unsound. See also 858.2. 
inar ${ }^{49}$ and leave the reader to decide whether or not he agrees with a conclusion that, in appropriate circumstances, the chance of a successful demand would be excellent.

\section{Royalty on Current Market Value or Proceeds of Sale}

The royalty on gas is usually expressed in the lease as "a royalty of one-eighth of the current market value at the well of gas produced from the said lands and marketed and used off the said lands" or "a royalty in an amount equal to the current market value at the well as and when produced of one-eighth of all leased substances produced, saved and sold from the said lands."

Without further ado, let us consider the Texas case of Foster v. Atlantic Refining Co. ${ }^{50}$ In that case the royalty clause read, in part as follows: 51

The conventional royalties to be paid by Lessee are: (a) On oil and gas, including all hydro-carbons, one-eighth (1/8th) of that produced and saved from said land, the same to be delivered to the credit of the Lessor into the pipe line and to be sold at the market price therefor prevailing for the field where produced when run;....

In 1950, Atlantic made a twenty-year gas sales contract covering the subject lease, among others. Prices payable to Atlantic during the disputed period were approximately 8.5 to 9.54 per $\mathrm{mcf}$ while the prevailing price for gas in the field was running at approximately 13 to $14 \uparrow$ per mcf. Foster claimed royalty based on the higher prevailing prices rather than on the prices fixed by Atlantic's sales contract. Atlantic argued:

1. That the market price is the price at which the gas was sold when the contract was entered into in 1950 and that the phrase "when run" can apply only to oil from stock tanks and that the gas was sold in 1950 for future delivery. The court said that it could see no reason why the phrase "when run" could not apply to delivery of gas from well to pipe line and that the 1950 contract was "an executory contract for the sale of gas with an executed sale of gas being effected when the gas came into possession of the pipeline;"52

2. That compliance with the royalty provisions as interpreted by Foster would be impossible because of the impossibility of including escalation provisions in the 1950 gas sales contract which would have assured the lessor of royalty on prevailing prices. The court held that "the inability of Atlantic to make a gas sales contract with escalation provisions is beside the point. The obligation of Atlantic to pay royalties is fixed and unambiguous. It made the gas sales contract with full knowledge of this obligation and did nothing to protect itself against increases in price. The fact that its purchaser would not agree to pay the market price prevailing at the time of delivery does not destroy the lease obligation". 53 The court then cited contract law on impossibility of performance which appears to be synonymous with the Alberta law on the subject, the latter being that "where there is a positive contract to do a thing, not in itself unlawful the contractor must perform it or pay damages for not doing it, although in conse-

\footnotetext{
49 Supra, n. 39.

so 329 F. 2d 485; 20 O. \& G. R. 422 (1964).

51 Id., 329 F. 2d 485 at 488; 20 O. \& G. R. 422 at 423 (1964).

52 Id., 329 F. 2d 485 at $489 ; 20$ O. \& G. R. 422 at 426 (1964).

s3 Id., 329 F. 2 d 485 at 489; 20 O. \& G. R. 422 at 425 (1964).
} 
quence of unforeseen accidents, the performance of his contract has become unexpectedly burdensome or even impossible". ${ }^{44}$

In stern language, reminiscent of Canadian oil and gas law cases, the court concluded: 55

Stripped of all the trimmings Atlantic's position is simply: We cannot comply. This is no answer. The lease calls for royalty based on the market price prevailing for the field where produced when run. The fact that the ascertainment of future market price may be troublesome or that the royalty provisions are improvident and result in a financial loss to Atlantic "is not a web of the Court's weaving." Atlantic cannot expect the court to rewrite the lease to Atlantic's satisfaction.

One might say that on the wording of the lease in the Foster case the conclusion that royalty must be paid on prevailing prices was inescapable but that had the royalty been payable on "market price at the well" the outcome might have been different. In Texas Oil and Gas Corp. v. Vela the lease provided "as royalty for gas from each well where gas only is found, while the same is being sold or used off the premises, one-eighth of the market price at the wells of the amount so sold or used,...."56 The court said:57

It is elemental contract law that since the lessor is not a party to the gas purchase contract entered into between lessee and a third party, he is not bound by the terms of same, if they are in conflict with lessee's obligations under the lease. However, we must not overlook the fact that gas is only sold under long-term contracts, and that a reasonably prudent operator, in the exercise of good faith, might be required to enter into such a contract.

In our opinion the proper rule is that the price paid under a gas purchase contract entered into between lessee and a third party is not necessarily the "market price" as provided for in the lease. However, this price, together with the circumstances of such contract, should be considered along with evidence of comparable sales to determine the market price.

In the Vela case the producer's 1935 gas sales contract was "for the life of the lease" and the sales price was 2.34 per mcf. By 1960 that price was approximately $11 థ$ per mof lower than the market price of gas in the area. Subject to the limitation period, the court permitted recovery of royalty on the difference.

Reducing or eliminating such claims by royalty owners can be accomplished by including a "favoured nations" clause ${ }^{58}$ or a periodic price renegotiation clause in the gas sales contract. The favoured nations clause might provide that the price to be paid for the gas by the purchaser will be increased from time to time to equal the price paid by the purchaser to other producers in the field and in other fields in the province. There would be little likelihood of obtaining a clause whereby the purchaser would meet sales prices offered by persons other than the purchaser but, because of continuous buying by a small number of major purchasers for export from Alberta, the unavailability of such a wide clause should not present problems. The periodic price renegotiation clause would provide that the price would be renegotiated from time to time based on such criteria as fair market value or reasonable price. One might also include provisions in the oil

\footnotetext{
s4 C.E.D. (Western) 2d, Vol. 5, at 172 and cases cited therein.

ss Supra, n. 50 at 490 and 426 .

so 405 S. W. 2 d 68 at $72 ; 25$ O. \& G. R. 253 at 255 (1966), modified 429 S. W. $2 d 866 ; 29$ O. \& G. R. 121 (1968).

37 Id., 405 S. W. $2 d 68$ at $74 ; 25$ O. \& G. R. 253 at 258.

se Permo Gas \& Oil Ltd. v. Pacific Petroleums Ltd. (1963) 40 D. L.R. (2d) 109.
} 
[VOL. IX

and gas lease whereby royalty is payable on proceeds of sale of leased substances and the lessee is given absolute discretion in sales, including term, price and duration of the sales contract. ${ }^{59}$

59 E.g., Williams and Meyers, supra, n. 15, Vol. 3 Sec. 650.4. 